\title{
Restructuring of benthic communities in eutrophic estuaries: lower abundance of prey leads to trophic shifts from omnivory to grazing
}

\author{
Sophia E. Fox ${ }^{1,2, *}$, Mirta Teichberg ${ }^{1,3}$, Ylva S. Olsen ${ }^{1,4}$, Leanna Heffner ${ }^{1,5}$, \\ Ivan Valiela ${ }^{1,2}$
}

\footnotetext{
${ }^{1}$ Boston University Marine Program, Marine Biological Laboratory, 7 MBL Street, Woods Hole, Massachusetts 02543, USA

${ }^{2}$ Present address: The Ecosystems Center, Marine Biological Laboratory, 7 MBL Street, Woods Hole, Massachusetts 02543, USA

${ }^{3}$ Present address: Zentrum für Marine Tropenökologie, Fahrenheitstrasse 6, 28359 Bremen, Germany

${ }^{4}$ Present address: School of Ocean Sciences, University of Bangor, Wales, Menai Bridge, Anglesey LL59 5AB, UK

${ }^{5}$ Present address: Graduate School of Oceanography, University of Rhode Island, 215 South Ferry Road, Narragansett, Rhode Island 02822, USA
}

\begin{abstract}
Anthropogenic nutrient loading to coastal waters has increased producer biomass, leading to more frequent hypoxic events particularly in estuarine systems. To examine how eutrophication and hypoxia might alter consumer assemblages, we surveyed benthic communities in 2 subestuaries of Waquoit Bay, Massachusetts, representing a eutrophic-hypoxic regime and an oligotrophic-oxic regime. The number of consumer species and abundance of organisms were lower in the eutrophic estuary. In particular, there were fewer primary consumers, mainly small crustaceans. These differences in consumer community structure also alter trophic interactions. To examine changes in food web structure that might result from lower prey abundance, we sampled organisms from the 2 sub-estuaries and determined their trophic relationships based on nitrogen stable isotope ratios. Reduced numbers of primary consumers, and hence lower prey availability, led to changes in food web linkages. Specifically, omnivores shifted their diets from an omnivorous diet that is mainly carnivorous in the oligotrophic estuary to feeding mainly as herbivores in the eutrophic estuary, where prey were scarce and macroalgae were abundant. These shifts in trophic structure may have consequences for higher trophic levels.
\end{abstract}

KEY WORDS: Eutrophication ' Hypoxia ' Benthic community ' Crustacean · Food web · Trophic structure $\cdot$ Macroalgae

Resale or republication not permitted without written consent of the publisher

\section{INTRODUCTION}

Anthropogenic nutrient inputs have led to widespread eutrophication of coastal marine environments (Duarte 1995). This nutrient enrichment has altered coastal communities so that $65 \%$ of US coastal environments studied showed moderate or severe symptoms of eutrophication (Bricker et al. 2007), and hypoxic conditions were observed in $75 \%$ of US coastal waters (Diaz 2001). As humans alter the coastal landscape, it becomes increasingly important to understand changes taking place at the species, community, and ecosystem levels. Cloern (2001) emphasized the importance of understanding the linkages of all parts of the ecosystem and many potential interacting responses to eutrophication.

The effects of land-derived nutrient inputs include increases in phytoplankton biomass (Nixon 1992) and proliferation of opportunistic macroalgal blooms in coastal waters worldwide (Valiela et al. 1992, Duarte 1995). Macroalgal blooms, in particular, have had further consequences, often shading and replacing seagrass meadows (McGlathery 2001, Hauxwell et al. 2001). Enrichment of coastal waters has also been correlated with lower dissolved oxygen concentrations in bottom waters, largely because of stimulated metabo- 
lism in these systems (Cloern 2001). High benthic macroalgal biomass increases the frequency and duration of intermittent hypoxia in stratified estuaries (D'Avanzo \& Kremer 1994, Diaz 2001). Respiration of benthic macroalgae and fauna can create hypoxic conditions in bottom waters overnight, and daytime photosynthesis of the macroalgae replenishes the oxygen consumed as well as producing an excess of oxygen, often driving concentrations to saturation (D'Avanzo \& Kremer 1994). Persistent hypoxia can, however, develop during a series of cloudy days, when photosynthesis does not produce enough oxygen to meet or exceed respiration demands (D'Avanzo \& Kremer 1994).

Eutrophication and the resulting hypoxia alter benthic consumer communities, often reducing benthic species richness (Harper et al. 1981, Sogard \& Able 1991, Diaz \& Rosenberg 2008), and decreasing the abundance of invertebrates (Baden et al. 1990, Tagliapietra et al. 1998, Österling \& Pihl 2001) and fish (Baden et al. 1990). The degree of ecological effects of hypoxia depends on minimum dissolved oxygen concentrations, duration of exposure to low oxygen, and the areal extent of hypoxic regions (Diaz \& Rosenberg 2001).

Changes in species composition and abundance associated with hypoxia may in turn create prey limitation and alter feeding habits of consumers that remain (Breitburg 1992, Pihl 1994, Österling \& Pihl 2001, Wennhage \& Pihl 2007, Jephson et al. 2008). Alterna- tively, increased primary production owing to nutrient supply can provide more food and shelter for higher trophic levels in both benthic and pelagic food webs (Sogard \& Able 1991, Ware \& Thompson 2005). These changes in composition and feeding behaviors of consumers may alter trophic relationships in estuaries subject to eutrophication and hypoxia.

Nitrogen stable isotopes $\left(\delta^{15} \mathrm{~N}\right)$ have been used to determine food web relationships (Peterson \& Fry 1987, McClelland et al. 1997, Martinetto et al. 2006) because consumers are enriched in $\delta^{15} \mathrm{~N}$ (more ${ }^{15} \mathrm{~N}$ than ${ }^{14} \mathrm{~N}$ ) relative to their food source (Minagawa \& Wada 1984). $\delta^{15} \mathrm{~N}$ signatures have also been used to determine sources of nitrogen entering coastal waters, with estuarine producers having heavier $\delta^{15} \mathrm{~N}$ values in eutrophic estuaries than in non-eutrophic estuaries owing to heavier $\delta^{15} \mathrm{~N}$ of the nitrogen source from human-derived wastewater (McClelland \& Valiela 1998a, Costanzo et al. 2001, Cole et al. 2004).

In the present study, we took advantage of estuaries subject to different levels of land-derived nitrogen loading to examine whether increased eutrophication can lead to differences in the benthic food web by changing the abundance of different species enough to shift trophic links, forcing consumers to change trophic position. To assess benthic community structure, we surveyed benthic organisms in a non-eutrophic and a eutrophic estuary. To determine food web linkages, we measured $\delta^{15} \mathrm{~N}$ values of benthic organisms in these 2 estuaries.

Table 1. Land-derived nitrogen loads, residence times, sediment character (mean $\pm \mathrm{SE}$ ), groundwater and water column nutrient concentrations (annual mean $\pm \mathrm{SE}$ ), seagrass and macroalgal biomass (mean $\pm \mathrm{SE}$ ), and eutrophication status of the 2 estuaries, Childs River (CR) and Sage Lot Pond (SLP)

\begin{tabular}{|c|c|c|c|}
\hline & $\mathrm{CR}$ & ry SLP & Source \\
\hline Nitrogen load ( $\left.\mathrm{kg} \mathrm{N} \mathrm{ha}^{-1} \mathrm{yr}^{-1}\right)$ & 601 & 12 & Bowen \& Valiela (2001) \\
\hline Water residence time $(\mathrm{d})$ & 2.0 & 1.5 & Carmichael \& Valiela (2005) \\
\hline \multicolumn{4}{|l|}{ Sediment character (\%) } \\
\hline Silt \& clay & $11.5 \pm 2.5$ & $5.5 \pm 3.5$ & Carmichael \& Valiela (2005) \\
\hline Sand & $94.0 \pm 3.0$ & $88.5 \pm 2.5$ & Carmichael \& Valiela (2005) \\
\hline \multicolumn{4}{|l|}{ Nutrient concentration $(\mu \mathrm{M})$} \\
\hline \multicolumn{4}{|l|}{$\mathrm{NO}_{3}$} \\
\hline Groundwater & $92.1 \pm 33.6$ & $7.2 \pm 2.0$ & Holmes (2008) \\
\hline Water column & $13.9 \pm 3.2$ & $0.3 \pm 0.1$ & Holmes (2008) \\
\hline \multicolumn{4}{|l|}{$\mathrm{NH}_{4}$} \\
\hline Groundwater & $5.7 \pm 1.7$ & $21.7 \pm 4.6$ & Holmes (2008) \\
\hline Water column & $1.4 \pm 0.2$ & $2.1 \pm 0.5$ & Holmes (2008) \\
\hline \multicolumn{4}{|l|}{$\mathrm{PO}_{4}$} \\
\hline Groundwater & 5.3 & 15.7 & Holmes (2008) \\
\hline Water column & $0.1 \pm 0$ & $0.1 \pm 0$ & Holmes (2008) \\
\hline Seagrass biomass ( $\mathrm{g}$ dry $\mathrm{wt}^{-2}$ ) & 0 & $43.7 \pm 3.3$ & Fox et al. (2008) \\
\hline Macroalgal biomass (g dry wt $\mathrm{m}^{-2}$ ) & $181 \pm 20$ & $46 \pm 9$ & Fox (2008) \\
\hline Eutrophication status & Eutrophic & Oligotrophic & Fox et al. (2008) \\
\hline
\end{tabular}




\section{MATERIALS AND METHODS}

Study sites. The Waquoit Bay estuarine system, located on Cape Cod, Massachusetts, is representative of shallow, groundwater-fed estuarine embayments in the northeastern USA. The estuaries of Waquoit Bay are typically shallow, from 1 to $3 \mathrm{~m}$ in depth, and range in salinity from 20 to $32 \mathrm{ppt}$ with the exception of 1 survey site in Childs River (CR) that ranges from 12 to $25 \mathrm{ppt}$, depending on the tide, recent precipitation, and season (S. Fox, unpubl. data). The 2 sub-estuaries are similar in many physical aspects (Table 1), including water residence time, sediment character, and light penetration to $1.5 \mathrm{~m}$ depth (M. Teichberg unpubl. data). The watersheds of these sub-estuaries, however, differ in their land covers (Fig. 1) and therefore deliver different nitrogen loads to the receiving estuaries, mainly through freshwater moving into the estuaries from groundwater inputs (Bowen \& Valiela 2001). The Sage Lot Pond (SLP) watershed comprises mainly a forested state park and delivers only $12 \mathrm{~kg} \mathrm{~N} \mathrm{ha}^{-1} \mathrm{yr}^{-1}$ to the estuary. In contrast, the wa- tershed of CR is suburbanized and delivers $601 \mathrm{~kg} \mathrm{~N} \mathrm{ha}^{-1}$ $\mathrm{yr}^{-1}$ to the estuary (Table 1, Fig. 1; Bowen \& Valiela 2001). This range of nitrogen loads encompasses approximately $75 \%$ of the range of reported loading values to estuaries worldwide (Nixon 1992).

The nitrogen loading rates of the 2 estuaries result in different levels of eutrophication. SLP is an oligotrophic estuary with low annual dissolved inorganic nitrogen (DIN) concentrations (Table 1), low mean macroalgal biomass (with a maximum single sample

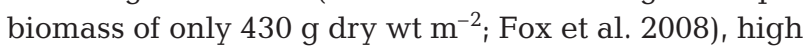
seagrass Zostera marina biomass (Hauxwell et al. 2001, Fox et al. 2008), and oxic waters (Table 2, Fig. 2a). In this non-eutrophic estuary, diel patterns of oxygen consumption by organisms and oxygen production by producers, mainly Z. marina, occur in the water column. Dissolved oxygen concentrations in SLP are rarely low enough to cause hypoxic conditions (Table 2, Fig. 2a), most likely because the oligotrophic conditions of this estuary do not support the high algal biomass characteristic of eutrophic estuaries.

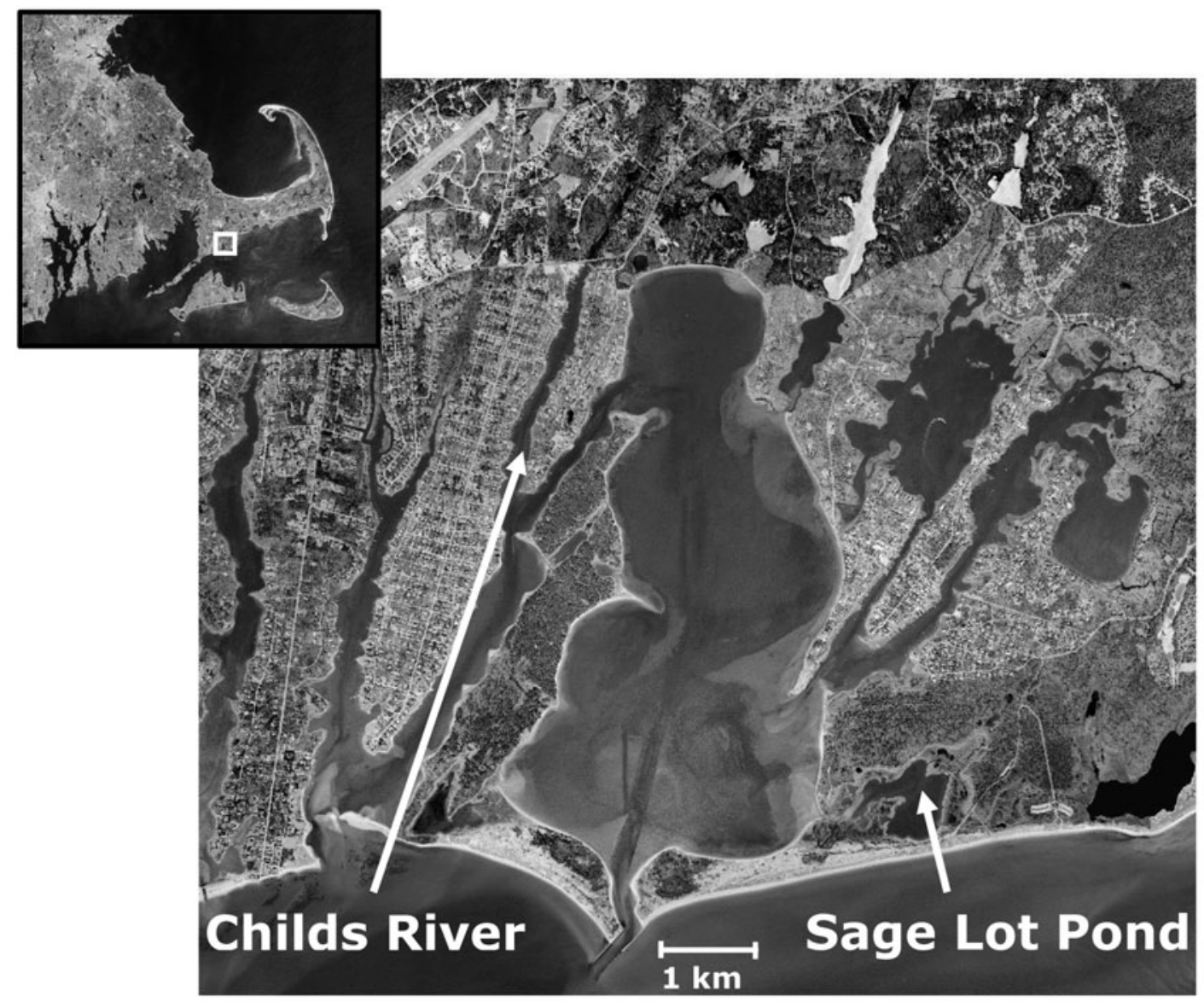

Fig. 1. Satellite image of southeastern Massachusetts (top left) with inset of Waquoit Bay enlarged to show the 2 estuaries Childs River (CR) and Sage Lot Pond (SLP). The CR watershed is suburbanized, with houses and roads shown in lighter tones, and SLP's watershed is mainly forested, indicated by darker shades. Source credit: Office of Geographic and Environmental Information (MassGIS), Commonwealth of Massachusetts Executive Office of Environmental Affairs 
Table 2. Percentage of days in July 2004 and 2005 with dissolved oxygen concentrations $<2 \mathrm{mg} \mathrm{l}^{-1}$ (dashed line in Fig. 2) and $<4 \mathrm{mg} \mathrm{l}^{-1}$ (within the shaded area in Fig. 2) in the noneutrophied Sage Lot Pond (SLP) and eutrophied Childs River (CR) estuaries

\begin{tabular}{|c|c|c|c|c|}
\hline \multirow{3}{*}{$\begin{array}{l}\text { Dissolved } \\
\text { oxygen }\end{array}$} & \multicolumn{4}{|c|}{$\longrightarrow$ Days $(\%)$} \\
\hline & 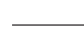 & - & 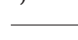 & 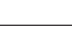 \\
\hline & 2004 & 2005 & 2004 & 2005 \\
\hline$<2 \mathrm{mg} \mathrm{l}^{-1}$ & 0 & 0 & 75 & 59 \\
\hline$<4 \mathrm{mg} \mathrm{l}^{-1}$ & 63 & 32 & 100 & 86 \\
\hline
\end{tabular}

In contrast, CR has a higher nitrogen load and higher DIN concentrations (Table 1), and experiences several symptoms of eutrophication (Valiela et al. 1992). Macroalgal biomass is high, with the maximum measured in a single sample as high as $1850 \mathrm{~g}$ dry wt m ${ }^{-2}$

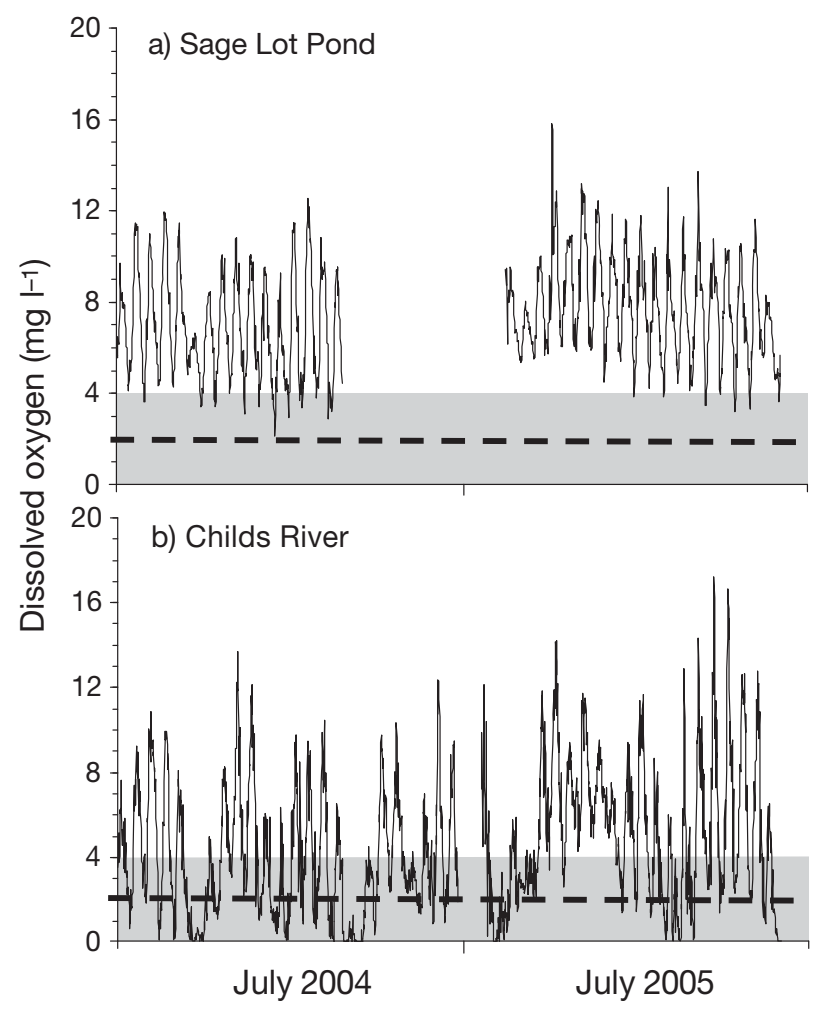

Fig. 2. Continuous dissolved oxygen concentrations in (a) Sage Lot Pond and (b) Childs River during the month of July in 2004 and 2005 (data courtesy of Waquoit Bay National Estuarine Research Reserve). Data were collected with YSI data loggers that were deployed continuously at a depth of $1 \mathrm{~m}$ (in the estuarine bottom waters) at a representative location in each of the 2 estuaries. Dashed line indicates dissolved oxygen concentration defined as hypoxia (Dauer et al. 1992, Rabalais et al. 2001), and shaded area indicates dissolved oxygen concentrations below which there are negative effects on benthic fauna (Coiro et al. 2000, Eriksson Wiklund \& Sundelin 2001)
(Fox et al. 2008). Although macroalgal biomass is much higher in CR than in SLP, the same species dominate the macroalgal communities: Cladophora vagabunda, Gracilaria tikvahiae, and Ulva lactuca. As a result of shading by the extensive macroalgal canopies, the eelgrass Zostera marina has disappeared from this estuary (Hauxwell et al. 2001, Fox et al. 2008). The high macroalgal biomass also dominates the oxygen regime of CR by releasing and consuming oxygen and leads to hypoxia of the bottom waters of the estuary (D'Avanzo \& Kremer 1994). This pattern is repeated each day dur-

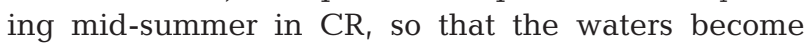
hypoxic on a daily basis (Table 2, Fig. 2b). After multiple cloudy days, persistent hypoxia of 2 to $3 \mathrm{~d}$ duration can develop (Fig. 2b).

The Waquoit Bay estuarine system provides an excellent location to investigate alterations to estuarine communities that occur in response to changes in nitrogen inputs to coastal waters. The land uses on the watersheds of the sub-estuaries of Waquoit Bay are representative of the region and impart different nutrient loading rates to receiving estuaries owing to different land covers on their watersheds (Bowen \& Valiela 2001). SLP and CR are located adjacent to one another, and thus experience similar regional climatic and tidal patterns, are similar in depth and water residence times (our Table 1; Hauxwell et al. 2001, Carmichael \& Valiela 2005), and have similar histories of an initial state as eelgrass meadows, as revealed by evidence of Zostera marina plants or seeds in all subestuaries of Waquoit Bay (Safran et al. 1998, Hauxwell et al. 2001). The major mechanism of change forced on the Waquoit Bay estuarine environment and ecosystem is development of the watershed, namely an increase in the number of houses and decrease in fringing salt marsh, which have led to increased delivery of nitrogen to estuarine waters (Valiela et al. 1992). Previous studies in the sub-estuaries of Waquoit Bay have made the case that, although there are differences among sub-estuaries in some aspects, the differences in nitrogen loading received from the land overwhelm the influence of other potential controls on nutrient and oxygen concentrations as well as phytoplankton, microphytobenthos, and macrophyte biomass, and higher trophic levels and food webs (Valiela et al. 1992, D'Avanzo \& Kremer 1994, McClelland et al. 1997, McClelland \& Valiela 1998b, Tober et al. 2000, Hauxwell et al. 2001, Millman et al. 2002, Lever \& Valiela 2005, Martinetto et al. 2006, Teichberg et al. 2007, Fox et al. 2008).

Consumer abundance. To evaluate differences in benthic invertebrate communities between SLP and $\mathrm{CR}$, we collected benthic organisms from 10 sites in each of the 2 estuaries. Since the focus of the present study was to examine the benthic communities associ- 
ated with macroalgae-dominated habitats, the 10 sites were distributed throughout the estuary within macroalgal canopies to representatively include shallow as well as deeper portions of the estuaries. The sampling sites were 300 to $500 \mathrm{~m}$ apart. In SLP, samples were taken in macroalgal canopies at least $10 \mathrm{~m}$ away from Zostera marina beds. At each site, a sample was collected using a $15 \times 15 \mathrm{~cm}$ Ekman benthic grab. The collected material was rinsed through a $1 \mathrm{~mm}$ sieve to remove mud and brought back to the laboratory to be sorted. In a qualitative analysis, we determined that a $1 \mathrm{~mm}$ sieve sufficiently sampled the macrofauna in this system, since few additional macroorganisms were retained on a $500 \mu \mathrm{m}$ sieve after passing through the $1 \mathrm{~mm}$ sieve. Organisms in each sample were preserved in $70 \%$ ethanol for identification and counting. Unfortunately, this method was not suitable for sampling fish, so we have not included fish in the abundance analysis.

To statistically examine whether abundance of individual taxa differed between the 2 estuaries, we used $t$ tests to examine differences between the 2 estuaries in abundance of each consumer and consumer groups. To examine the similarity in species composition between the 2 estuaries, we calculated the Jaccard's index, a similarity index based on presence/absence data.

Stable isotopic study of macroalgae-based food webs. To examine differences in trophic links within the macroalgae-based food webs of SLP and CR, we sampled macroalgae and benthic invertebrates and fish in 9 macroalgae-dominated sites in each of the 2 estuaries. Samples were taken using a $30 \times 20 \times 20 \mathrm{~cm}$ (length $\times$ width $\times$ height) dip net with $1 \mathrm{~mm}$ mesh size dragged along the sediment surface in 3 locations through the macroalgal canopy for a distance of $1 \mathrm{~m}$ at each site. Collected material, including macroalgae invertebrates, and fish, was sieved to remove mud and stored in a fine mesh bag to prevent anoxia within the sample during transport to the laboratory. The samples were sorted live to the species level until 10 to 50 ind. of each species present in the sample were collected for isotopic analysis. Rarer species may have had fewer than 10 ind. To ensure that the analysis measured only food material assimilated in the tissues of the animals, organisms of each species were placed in individual containers with filtered seawater for $24 \mathrm{~h}$ to allow for evacuation of gut contents, and guts were removed from larger organisms. Specimens of all species of macroalgae and consumers were then rinsed with deionized water to remove salts, dried at $60^{\circ} \mathrm{C}$ for $48 \mathrm{~h}$, and ground into a fine powder. $\delta^{15} \mathrm{~N}$ values were determined by mass spectrometry at the Stable Isotope Facility, University of California at Davis.

To normalize the $\delta^{15} \mathrm{~N}$ data for differences in nitrogen sources entering the estuaries and allow for direct comparison of trophic linkages between species from the 2 estuaries, $\delta^{15} \mathrm{~N}$ values were normalized by subtracting the mean $\delta^{15} \mathrm{~N}$ value of all macroalgal species collected within each estuary $(4.05 \%$ for SLP and $7.54 \%$ o for $\mathrm{CR}$ ) from the $\delta^{15} \mathrm{~N}$ values of the producers and consumers from that estuary. The mean value of $\delta^{15} \mathrm{~N}$ of macroalgae was subtracted because macroalgal $\delta^{15} \mathrm{~N}$ values are indicators of nitrogen enrichment to the estuary and this enrichment is transferred via algae up the food web to consumers (McClelland et al. 1997, McClelland \& Valiela 1998a, Cole et al. 2004).

To determine differences in the trophic positions of consumers between the 2 estuaries, we initially used literature reports of feeding habits to sort the taxa into trophic categories (Zimmerman et al. 1979, Nelson 1979, Morgan 1980, Nicotri 1980, Heck \& Thoman 1981, Kneib 1985, McClelland et al. 1997, McClelland \& Valiela 1998b, MacNeil et al. 1999, Griffin \& Valiela 2001, McCurdy et al. 2005, Martinetto et al. 2006). We then pooled the taxa into macroalgae, grazers, omnivores, and predators. Only taxa for which there was published information on diets were included in the stable isotopic analysis. Information was available on feeding habits for about $85 \%$ of the number of organisms and $50 \%$ of the taxa found in our abundance survey samples.

To statistically examine whether there were differences in trophic structure between the 2 estuaries, we examined abundance and stable isotope data separately. We used $t$-tests to examine differences between the 2 estuaries in the abundance of consumers at the grazer, omnivore, and predator trophic levels. To determine differences in normalized $\delta^{15} \mathrm{~N}$ values of consumers in each estuary at the different trophic levels, we performed an ANOVA using a partial hierarchical design (Brownlee 1965).

\section{RESULTS}

\section{Benthic community structure}

The benthic communities of macroalgae-dominated sub-strata differed between the 2 estuaries. The species richness was lower in the eutrophic estuary, CR, with one-third fewer taxa than in SLP (Table 3). The Jaccard's index for similarity between species composition in the 2 estuaries was $J=0.45$, meaning that only about half the species were found in both the eutrophic and non-eutrophic estuaries. Taxa tended to be missing from CR rather than SLP, and consisted mainly of amphipods, isopods, and 'other crustaceans,' with a 3 -fold reduction in the number of these taxa from 21 to 7 species (Table 3 ). The remaining groups of organisms did not differ significantly in the number of taxa between the 2 estuaries. 
Table 3. Number of species in taxonomic groups found in the non-eutrophied Sage Lot Pond (SLP) and eutrophied Childs River (CR) estuaries, and the difference between the 2 estuaries. Positive difference indicates lower abundance in CR than in SLP

\begin{tabular}{|c|c|c|c|}
\hline \multirow{2}{*}{ Taxon } & \multicolumn{2}{|c|}{ —Estuary- } & \multirow[b]{2}{*}{ Difference } \\
\hline & SLP & $\mathrm{CR}$ & \\
\hline Amphipods & 11 & 5 & 6 \\
\hline Isopods & 5 & 2 & 3 \\
\hline Crabs & 1 & 2 & -1 \\
\hline Shrimp & 3 & 3 & 0 \\
\hline Other crustaceans & 5 & 0 & 5 \\
\hline Gastropods & 7 & 7 & 0 \\
\hline Bivalves & 2 & 2 & 0 \\
\hline Polychaetes & 16 & 15 & 1 \\
\hline Nemerteans & 3 & 1 & 2 \\
\hline Other & 6 & 3 & 3 \\
\hline Total & 59 & 40 & 19 \\
\hline
\end{tabular}

Abundances of benthic organisms in macroalgal habitats were 7 -fold lower in the eutrophic estuary than in the non-eutrophic estuary (Table 4). The major reduction in abundance was seen in small crustaceans, which decreased by 2 orders of magnitude from approximately 11000 to 100 ind. $\mathrm{m}^{-2}$ between the 2 estuaries. The abundance of most taxa tended to decrease from SLP to CR: $22 \%$ significantly decreased while only $3 \%$ significantly increased (Table 4 ).

Most small crustaceans (amphipods, isopods, and 'other crustaceans') were abundant in the noneutrophic estuary, while only 2 small crustaceans (the isopod Edotea triloba and the amphipod Gammarus mucronatus) were common in the eutrophic estuary (Table 4). E. triloba was common in both estuaries, occurring at $40 \%$ of the survey sites in CR and $90 \%$ of the sites in SLP. G. mucronatus was also found in both

Table 4. (Below and facing page). Mean $\pm \mathrm{SE}$ abundance (ind. $\mathrm{m}^{-2}$ ) of taxa in the non-eutrophied Sage Lot Pond (SLP) and eutrophied Childs River (CR) estuaries, mean difference in number of individuals between the 2 estuaries, and results of $t$-tests for differences between means. Positive difference between means indicates lower abundance in CR than in SLP. ns = not significant

\begin{tabular}{|c|c|c|c|c|c|}
\hline \multirow[t]{2}{*}{ Taxon } & \multicolumn{2}{|c|}{ - Estuary - } & \multirow[t]{2}{*}{ Difference } & \multirow[t]{2}{*}{$t$} & \multirow[t]{2}{*}{$\mathrm{p}$} \\
\hline & SLP & CR & & & \\
\hline Amphipods & $7556 \pm 1987$ & $53 \pm 26$ & 7503 & 3.77 & 0.002 \\
\hline Microdeutopus spp. & $3111 \pm 1145$ & $4 \pm 4$ & 3107 & 2.71 & 0.011 \\
\hline Corophium spp. & $1591 \pm 617$ & $0 \pm 0$ & 1591 & 2.58 & 0.014 \\
\hline Lysianopsis alba & $1169 \pm 465$ & $4 \pm 4$ & 1165 & 2.51 & 0.017 \\
\hline Cymadusa compta & $1058 \pm 494$ & $4 \pm 4$ & 1054 & 2.13 & 0.031 \\
\hline Amphithoe longimana & $342 \pm 142$ & $0 \pm 0$ & 342 & 2.41 & 0.020 \\
\hline Ampelisca sp. & $27 \pm 18$ & $0 \pm 0$ & 27 & 1.50 & ns \\
\hline Gammarus mucronatus & $182 \pm 94$ & $36 \pm 25$ & 146 & 1.52 & ns \\
\hline Leptocheirus sp. & $0 \pm 0$ & $4 \pm 4$ & -4 & 1.00 & ns \\
\hline Calliopius laeviusculus & $4 \pm 4$ & $0 \pm 0$ & 4 & 1.00 & ns \\
\hline Unidentified amphipods & $53 \pm 36$ & $0 \pm 0$ & 53 & 1.47 & ns \\
\hline Isopods & $3151 \pm 1447$ & $53 \pm 30$ & 3098 & 2.14 & 0.030 \\
\hline Erichsonella filiformis & $804 \pm 213$ & $9 \pm 6$ & 795 & 3.74 & 0.002 \\
\hline Edotea triloba & $613 \pm 296$ & $44 \pm 27$ & 569 & 1.91 & 0.044 \\
\hline Cyathura polita & $89 \pm 42$ & $0 \pm 0$ & 89 & 2.10 & 0.032 \\
\hline Leptochelia sp. & $1529 \pm 1437$ & $0 \pm 0$ & 1529 & 1.06 & ns \\
\hline Unidentified isopod & $116 \pm 106$ & $0 \pm 0$ & 116 & 1.09 & ns \\
\hline Crabs & $22 \pm 15$ & $13 \pm 7$ & 9 & 0.53 & ns \\
\hline Rhithropanopeus harrisii & $22 \pm 15$ & $9 \pm 6$ & 13 & 0.82 & ns \\
\hline Libinia dubia & $0 \pm 0$ & $4 \pm 4$ & -4 & 1.00 & $\mathrm{~ns}$ \\
\hline Shrimp & $182 \pm 80$ & $453 \pm 231$ & -271 & 1.11 & ns \\
\hline Palaemonetes spp. & $173 \pm 80$ & $449 \pm 231$ & -276 & 1.13 & ns \\
\hline Crangon septemspinosa & $9 \pm 9$ & $4 \pm 4$ & 5 & 0.45 & ns \\
\hline Other crustaceans & $53 \pm 16$ & $\mathbf{0} \pm \mathbf{0}$ & 53 & 3.50 & 0.003 \\
\hline Limulus polyphemus & $9 \pm 6$ & $0 \pm 0$ & 9 & 1.50 & ns \\
\hline Mysidae sp. & $18 \pm 10$ & $0 \pm 0$ & 18 & 1.81 & 0.052 \\
\hline Callipallene brevirostris & $18 \pm 10$ & $0 \pm 0$ & 18 & 1.00 & 0.052 \\
\hline Insect larvae & $4 \pm 4$ & $0 \pm 0$ & 4 & 1.81 & ns \\
\hline Cumaceans & $4 \pm 4$ & $0 \pm 0$ & 4 & 1.00 & ns \\
\hline Gastropods & $1920 \pm 1150$ & $916 \pm 170$ & 1004 & 0.86 & ns \\
\hline Hydrobia minuta & $1827 \pm 1156$ & $227 \pm 109$ & 1600 & 1.38 & ns \\
\hline Ilyanassa obsoleta & $9 \pm 6$ & $600 \pm 143$ & -591 & 4.14 & 0.001 \\
\hline Crepidula sp. & $18 \pm 14$ & $4 \pm 4$ & 14 & 0.93 & ns \\
\hline Bittium alternatum & $0 \pm 0$ & $53 \pm 32$ & -53 & 1.65 & ns \\
\hline Mitrella sp. & $9 \pm 6$ & $22 \pm 18$ & -13 & 0.71 & ns \\
\hline
\end{tabular}


Table 4 (continued)

\begin{tabular}{|c|c|c|c|c|c|}
\hline \multirow[t]{2}{*}{ Taxon } & \multicolumn{2}{|c|}{-Estuary - } & \multirow[t]{2}{*}{ Difference } & \multirow[t]{2}{*}{$t$} & \multirow[t]{2}{*}{$\mathrm{p}$} \\
\hline & SLP & CR & & & \\
\hline \multicolumn{6}{|l|}{ Gastropods (continued) } \\
\hline Lunatia sp. & $18 \pm 7$ & $4 \pm 4$ & 14 & 1.57 & ns \\
\hline Haminoea solitara & $36 \pm 36$ & $0 \pm 0$ & 36 & 1.00 & ns \\
\hline Unidentified gastropods & $4 \pm 4$ & $4 \pm 4$ & 0 & 0.00 & ns \\
\hline Bivalves & $5262 \pm 1725$ & $124 \pm 96$ & 5138 & 2.97 & 0.008 \\
\hline Polychaetes & $5431 \pm 1291$ & $1236 \pm 273$ & 4195 & 3.18 & 0.005 \\
\hline Podarke obscura & $613 \pm 136$ & $213 \pm 72$ & 400 & 2.60 & 0.011 \\
\hline Unidentified Nereis sp. & $0 \pm 0$ & $49 \pm 40$ & -49 & 1.22 & ns \\
\hline N. arenoceodonta & $227 \pm 59$ & $0 \pm 0$ & 227 & 3.87 & 0.002 \\
\hline N. succinea & $147 \pm 59$ & $169 \pm 66$ & -22 & 0.25 & ns \\
\hline Orbina ornata & $258 \pm 137$ & $98 \pm 62$ & 160 & 1.06 & ns \\
\hline Polycirrus eximius & $3009 \pm 1264$ & $4 \pm 4$ & 3005 & 2.38 & 0.021 \\
\hline Cirratulus cirratus & $84 \pm 39$ & $0 \pm 0$ & 84 & 2.14 & 0.030 \\
\hline Unidentified terebellid & $49 \pm 27$ & $0 \pm 0$ & 49 & 1.82 & 0.051 \\
\hline Polydora ligni & $191 \pm 152$ & $178 \pm 70$ & 13 & 0.08 & ns \\
\hline Scolecolepides viridis & $22 \pm 12$ & $49 \pm 44$ & -27 & 0.58 & ns \\
\hline Streblospio benedicti & $124 \pm 49$ & $147 \pm 85$ & -23 & 0.23 & ns \\
\hline Unidentified spionid & $164 \pm 81$ & $0 \pm 0$ & 164 & 2.03 & 0.036 \\
\hline Capitellidae & $262 \pm 124$ & $253 \pm 162$ & 9 & 0.04 & ns \\
\hline Phyllodoce sp. & $0 \pm 0$ & $18 \pm 18$ & -18 & 1.00 & ns \\
\hline Eteone sp. & $9 \pm 9$ & $4 \pm 4$ & 5 & 0.45 & ns \\
\hline Eumidia sanguinea & $31 \pm 27$ & $0 \pm 0$ & 31 & 1.17 & ns \\
\hline Eulalia sp. & $120 \pm 120$ & $0 \pm 0$ & 120 & 1.00 & ns \\
\hline Harmathoe imbricata & $0 \pm 0$ & $4 \pm 4$ & -4 & 1.00 & ns \\
\hline Clymenella torquata & $0 \pm 0$ & $4 \pm 4$ & -4 & 1.00 & ns \\
\hline Arabella iricolor & $4 \pm 4$ & $0 \pm 0$ & 4 & 1.00 & ns \\
\hline Glycera sp. & $18 \pm 18$ & $0 \pm 0$ & 18 & 1.00 & ns \\
\hline Hypaniola grayi & $0 \pm 0$ & $18 \pm 18$ & -18 & 1.00 & ns \\
\hline Unidentified polychaete & $0 \pm 0$ & $13 \pm 7$ & -13 & 1.96 & 0.041 \\
\hline Nemerteans & $156 \pm 36$ & $53 \pm 24$ & 103 & 2.35 & 0.016 \\
\hline Fish & $36 \pm 15$ & $13 \pm 7$ & 23 & 1.39 & ns \\
\hline Other & $436 \pm 179$ & $173 \pm 88$ & 263 & 1.30 & ns \\
\hline Haliplanella luciae & $36 \pm 25$ & $13 \pm 9$ & 23 & 0.84 & ns \\
\hline Leptosynapta sp. & $40 \pm 40$ & $0 \pm 0$ & 40 & 1.00 & ns \\
\hline Molgula sp. & $324 \pm 172$ & $151 \pm 88$ & 173 & 0.89 & ns \\
\hline Euplana gracilis & $4 \pm 4$ & $0 \pm 0$ & 4 & 1.00 & ns \\
\hline Sclerodactyla briarus & $0 \pm 0$ & $4 \pm 4$ & -4 & 1.00 & ns \\
\hline Unidentified echinoderm & $31 \pm 22$ & $9 \pm 6$ & 22 & 0.97 & ns \\
\hline Total & $24213 \pm 3277$ & $3093 \pm 441$ & 21120 & 6.39 & 0.000 \\
\hline
\end{tabular}

estuaries but was relatively rarer in the eutrophic estuary (Table 4), occurring at only $20 \%$ of the survey sites in CR compared to $70 \%$ in SLP. Shrimp of the genus Palaemonetes, small bivalves, and nemerteans were also found in both estuaries. Gastropod and polychaete species were variously affected in the 2 estuaries; some were more abundant in SLP and some in CR, while many were common in both estuaries (Table 4). The species showing notable differences in abundance between the 2 estuaries were Ilyanassa obsoleta, Bittium alternatum, and an unidentified polychaete, which were more abundant in the eutrophic estuary, and Nereis arenoceodonta, Polycirrus eximius, Cirratulus cirratus, and 2 unidentified polychaetes, a spionid, and a terebellid, which were more abundant in the non-eutrophic estuary. A gastropod, a nemertean, and
6 species of polychaetes were ubiquitous in both estuaries, and the rest of the species were relatively rare. Almost half of the species surveyed were rare. Rare species, defined as species found at 0 to $20 \%$ of the survey sites in both estuaries, might be more susceptible to eutrophication and hypoxia than common species, since $61 \%$ of the rare species were found only in SLP, and about one-third that amount were found only in $\mathrm{CR}$.

\section{Benthic food web}

The number of species at each trophic level in the abundance survey differed between the 2 estuaries (Table 5). These species are consumers for which 
dietary information is available and include approximately half of the species listed in Table 4 . The number of species found only in SLP was larger than that of species only occurring in $\mathrm{CR}$, and there were also more grazer species in SLP (Table 5). Most species represented in Tables 5 \& 6, however, were found in both estuaries.

The abundance of grazers (predominantly amphipods, isopods, and gastropods) was significantly lower in the eutrophic estuary than in the non-eutrophic estuary, with an almost 25 -fold decrease (Table 6). The abundance of omnivores (mostly decapods) did not significantly differ between estuaries (Table 6). Fewer predators were sampled in CR than in SLP, and preda-

Table 5. Number of species occupying each trophic level from the abundance survey found only in the non-eutrophied Sage Lot Pond (SLP) estuary and only in the eutrophied Childs River (CR) estuary, the number of species per trophic level found in both estuaries, and the total number of species included in the trophic level abundance analysis

\begin{tabular}{|lcrrr|}
\hline \multirow{2}{*}{ Trophic position } & \multicolumn{3}{c}{ Estuary } & \multicolumn{1}{c|}{} \\
\cline { 2 - 4 } & SLP & CR & Both & Total \\
\hline Grazers & 5 & 1 & 13 & 19 \\
Omnivores & 3 & 2 & 8 & 13 \\
Predators & 1 & 2 & 2 & 5 \\
Total & 9 & 5 & 23 & 37 \\
\hline
\end{tabular}

Table 6. Mean $\pm \mathrm{SE}$ abundance of grazers, omnivores, and predators in the non-eutrophied Sage Lot Pond (SLP) and eutrophied Childs River (CR) estuaries, and results of $t$-tests for differences between the mean values. ${ }^{* *} p=0.001-0.01$, ${ }^{* * *} \mathrm{p}<0.001, \mathrm{~ns}=$ not significant $(\mathrm{p}>0.05)$

\begin{tabular}{|c|c|c|c|}
\hline \multirow{2}{*}{$\begin{array}{l}\text { Trophic } \\
\text { position }\end{array}$} & \multicolumn{2}{|c|}{ — Estuary } & \multirow[b]{2}{*}{$t$} \\
\hline & SLP & CR & \\
\hline Grazers & $18396 \pm 2619$ & $764 \pm 231$ & $6.36^{* * *}$ \\
\hline Omnivores & $222 \pm 52$ & $222 \pm 69$ & $3.12 \times 10^{-16} \mathrm{~ns}$ \\
\hline Predators & $631 \pm 128$ & $213 \pm 68$ & $2.73^{* *}$ \\
\hline
\end{tabular}

Table 7. Mean \pm SE $\delta^{15} \mathrm{~N}(\%)$ of macroalgae, grazers, omnivores, and predators, identified as per published reports (see 'Materials and methods'), differences between the mean $\delta^{15} \mathrm{~N}$ for each trophic group, and mean $\pm \mathrm{SE}$ normalized $\delta^{15} \mathrm{~N}(\%)$ in the non-eutrophied Sage Lot Pond (SLP) and eutrophied Childs River (CR) estuaries

\begin{tabular}{|c|c|c|c|c|c|}
\hline \multirow{2}{*}{$\begin{array}{l}\text { Trophic } \\
\text { position }\end{array}$} & \multicolumn{2}{|c|}{$-\delta^{15} \mathrm{~N}$} & \multirow{2}{*}{ Difference } & \multicolumn{2}{|c|}{ Normalized $\delta^{15} \mathrm{~N}$} \\
\hline & SLP & $\mathrm{CR}$ & & SLP & $\mathrm{CR}$ \\
\hline Macroalgae & $3.41 \pm 0.17$ & $6.28 \pm 0.21$ & 2.9 & $-0.64 \pm 0.17$ & $-1.26 \pm 0.21$ \\
\hline Grazers & $4.33 \pm 0.11$ & $7.72 \pm 0.28$ & 3.4 & $0.28 \pm 0.11$ & $0.72 \pm 0.63$ \\
\hline Omnivores & $6.07 \pm 0.17$ & $8.48 \pm 0.17$ & 2.4 & $2.02 \pm 0.17$ & $1.18 \pm 0.21$ \\
\hline Predators & $8.08 \pm 0.23$ & $11.46 \pm 0.44$ & 3.4 & $4.17 \pm 0.23$ & $4.32 \pm 0.38$ \\
\hline
\end{tabular}
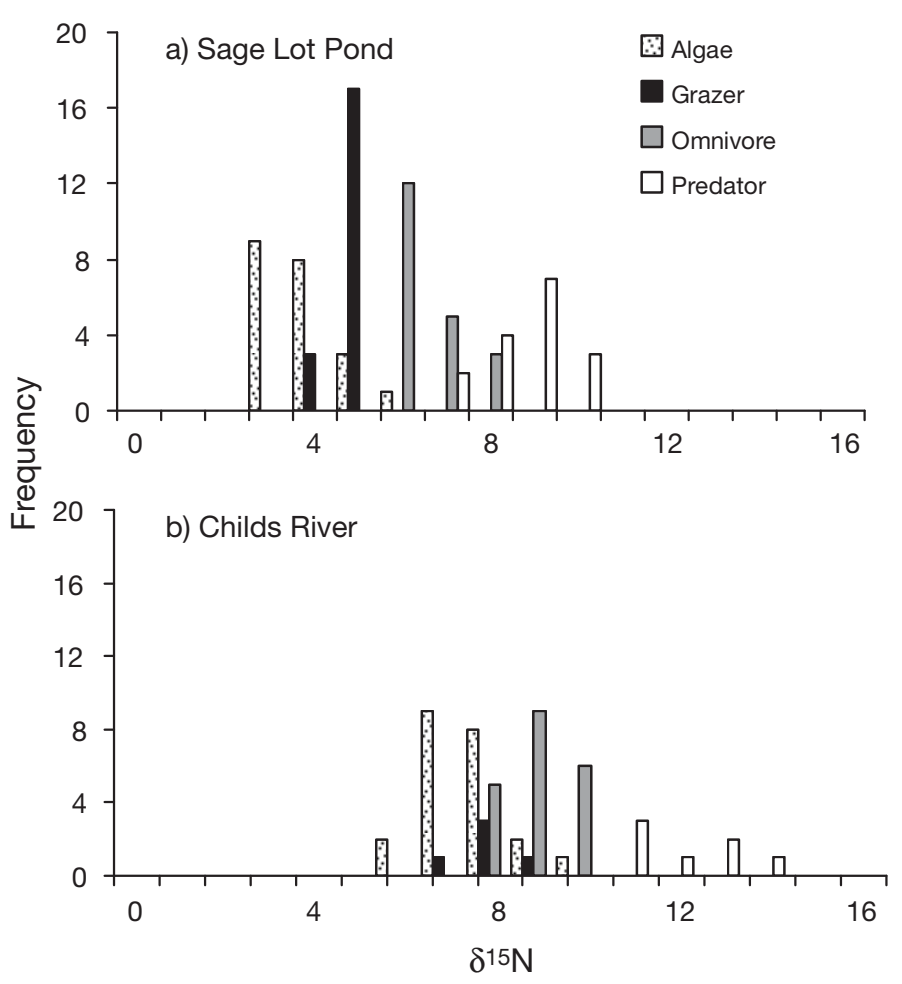

Fig. 3. $\delta^{15} \mathrm{~N}$ signatures of macroalgae, grazers, omnivores, and predators in (a) Sage Lot Pond and (b) Childs River. Taxa were identified as producers, grazers, omnivores, and predators using reports from the literature (see 'Materials and methods')

tors consisted mainly of the predatory polychaetes Podarke obscura and Glycera sp. Larger, more mobile predators, such as fish, were not well sampled using the benthic grab.

To test whether the lower abundance of prey affected the trophic position of estuarine consumers, we compared the $\delta^{15} \mathrm{~N}$ values for these taxa within each estuary. Nitrogen stable isotope analysis revealed differences in $\delta^{15} \mathrm{~N}$ values between the 2 estuaries. In all cases, $\delta^{15} \mathrm{~N}$ of producers and consumers from $\mathrm{CR}$ were higher than those from SLP (Table 7, Fig. 3) because of heavier $\delta^{15} \mathrm{~N}$ inputs from wastewater coming from the more urbanized watershed of CR (McClelland \& Valiela 1998a, Cole et al. 2004). Within each estuary, there was an increase in $\delta^{15} \mathrm{~N}$ with increasing trophic level-for example, the $\delta^{15} \mathrm{~N}$ value of producers was lower than that of grazers, and so on up the food web (Table 7). The differences between CR and SLP $\delta^{15} \mathrm{~N}$ values per trophic level were reasonably uniform $(2.9$ to $3.4 \%)$, except for the omnivores, where the difference was only $2.4 \%$ 
(Table 7 ). This difference in $\delta^{15} \mathrm{~N}$ values of the omnivores suggested a change in trophic step for the group, with CR omnivores having lighter $\delta^{15} \mathrm{~N}$ values than would be expected for organisms feeding omnivorously in this estuary.

To ascertain whether the trophic position of omnivores in CR and SLP differed relative to feeding habits reported in the literature, we compared the $\delta^{15} \mathrm{~N}$ values of trophic groups within each estuary. In this analysis, we were not concerned with differences in $\delta^{15} \mathrm{~N}$ values owing to different nitrogen sources entering the estuaries, and we knew that $\delta^{15} \mathrm{~N}$ of external nitrogen sources propagated up in each food web (McClelland et al. 1997, Martinetto et al. 2006). To directly compare trophic linkages, we normalized the $\delta^{15} \mathrm{~N}$ values of all producers and consumers against the mean $\delta^{15} \mathrm{~N}$ values for macroalgae from that estuary (Table 7). By normalizing the data, we removed the effect of ${ }^{15} \mathrm{~N}$ enrichment from nitrogen sources, so that we could focus on and compare the relative differences in $\delta^{15} \mathrm{~N}$ values for producers, grazers, omnivores, and predators within each estuary. There were no significant effects of estuary (Table 8), so that indeed normalizing data eliminated between-estuary differences in $\delta^{15} \mathrm{~N}$ values owing to nitrogen sources.

The 2 estuaries differed in the mean normalized $\delta^{15} \mathrm{~N}$ values of omnivores relative to grazers, with the $\delta^{15} \mathrm{~N}$ values of omnivores being similar to those of grazers in $\mathrm{CR}$ and relatively more distinct from those of grazers in SLP (Table 7 ). In SLP, the $\delta^{15} \mathrm{~N}$ values of omnivores only overlapped with predators, whereas in $\mathrm{CR}$, omnivores overlapped considerably with grazers rather than predators (Fig. 3). There were significant differences among the 4 trophic groups between the 2 estuaries (Tables $7 \& 8$ ), and within each estuary, $\delta^{15} \mathrm{~N}$ values also significantly differed among the trophic groups (Tables $7 \& 8$ ). In $\mathrm{CR}$, the $\delta^{15} \mathrm{~N}$ values of omnivores were not significantly different from the those of grazers $(p=0.982)$, and the $\delta^{15} \mathrm{~N}$ values of omnivores were significantly different from those of grazers in

Table 8. ANOVA of combined effects of estuary, site nested within estuary, and trophic position on normalized $\delta^{15} \mathrm{~N}$ of producers and consumers from the 2 estuaries. ${ }^{*} \mathrm{p}=$ $0.01-0.05,{ }^{* *} \mathrm{p}=0.001-0.01,{ }^{* * *} \mathrm{p}<0.001, \mathrm{~ns}=$ not significant $(\mathrm{p}>0.05)$

\begin{tabular}{|lrrc|}
\hline Source & df & MS & \multicolumn{1}{c|}{$F$} \\
\hline Estuary & 1 & 0.09 & $0.12 \mathrm{~ns}$ \\
Site (Estuary) & 5 & 3.67 & $4.96^{* *}$ \\
Trophic & 3 & 72.89 & $98.69^{* * *}$ \\
Estuary $\times$ Trophic & 3 & 2.02 & $2.74^{*}$ \\
Trophic $\times$ Site (Estuary) & 15 & 0.52 & $0.71 \mathrm{~ns}$ \\
Error & 66 & 0.74 & \\
\hline
\end{tabular}

SLP $(p=0.002)$. In both estuaries, the $\delta^{15} \mathrm{~N}$ values of omnivores were significantly different from those of predators ( $p<0.001$ for both comparisons). Organisms that have been reported to feed omnivorously in the literature tended to be feeding as herbivores in $\mathrm{CR}$, the eutrophic estuary, where prey were limited. In SLP, where many more prey were available (Tables 4 \& 6), omnivores remained omnivorous, with more prey in their diet and less of their diet coming from herbivory.

There appeared to be differences in the change in mean $\delta^{15} \mathrm{~N}$ among trophic levels between the 2 estuaries (Table 7). The difference between mean $\delta^{15} \mathrm{~N}$ of grazers and omnivores was larger in SLP than in CR, while the difference in mean $\delta^{15} \mathrm{~N}$ between omnivores and predators was larger in CR than in SLP (Table 7). The lack of a pattern in what is known as trophic fractionation observed in these data is likely owing to the diversity of organisms and to organisms of different sizes constituting each trophic level. For example, grazers include amphipods and isopods as well as the taxonomically and anatomically very different bivalves, gastropods, and echinoderms. Organisms will fractionate nitrogen differently depending on their prey, metabolism, taxonomy, and size (Macko et al. 1982, Vander Zanden \& Rasmussen 2001, Vanderklift \& Ponsard 2003, Crawley et al. 2007).

To determine whether taxa that differed in abundance between CR and SLP were feeding differently in the 2 estuaries, we compared stable isotope values for selected taxa from both sites. There were no consistent patterns in diet switching between individual taxa, with some of the invertebrate species showing diet differences between the 2 estuaries, while others did not. The amphipod Gammarus mucronatus was herbivorous in the non-eutrophic estuary and omnivorous in the eutrophic estuary (normalized $\delta^{15} \mathrm{~N}$ value of 0.62 in SLP and 1.45 in CR). In contrast, the grass shrimp Palaemonetes spp. were more herbivorous in the eutrophic estuary than in the non-eutrophic estuary (normalized $\delta^{15} \mathrm{~N}$ value of 2.63 in SLP and 1.1 in CR), and the mud snail Ilyanassa obsoleta, which is known to be omnivorous, was a strict grazer in CR (normalized $\delta^{15} \mathrm{~N}$ value of 0.59 ). The 5 fish species sampled, Fundulus heteroclitus, F. majalis, Apeltes quadracus, Anguilla rostrata, and Menidia menidia, were strict predators in all samples (normalized $\delta^{15} \mathrm{~N}$ values from 3.47 to 5.79 ).

Although feeding behaviors of some species differed from the rest of their trophic level, most consumers in a given trophic level within an estuary had similar $\delta^{15} \mathrm{~N}$ values. The relative change (coefficient of variation) among the $\delta^{15} \mathrm{~N}$ values for each trophic level were small and uniform (Table 9), showing that the consumers classified as grazers, for example, had similar $\delta^{15} \mathrm{~N}$ values, and thus were feeding at the same trophic 
Table 9. Coefficients of variation for $\delta^{15} \mathrm{~N}$ values of consumers in the 3 trophic levels in the Sage Lot Pond (SLP) and Childs River (CR) estuaries

\begin{tabular}{|lcr|}
\hline \multirow{2}{*}{ Trophic level } & \multicolumn{2}{c|}{ Estuary } \\
\cline { 2 - 3 } & SLP & CR \\
\hline Grazers & 11 & 8 \\
Omnivores & 16 & 11 \\
Predators & 11 & 9 \\
\hline
\end{tabular}

level. These data further support the notion that the trophic changes observed in CR omnivores are widespread throughout the community, as opposed to being only species-specific diet switches.

\section{DISCUSSION}

The results of the present study show that the 2 estuaries differed significantly in benthic community structure, with much lower total number and abundances of benthic consumers in the eutrophic estuary compared to the non-eutrophic estuary. In the eutrophic estuary, changes in prey availability are likely leading to shifts in feeding habits of consumers and changes to food web structure. Eutrophication and associated hypoxia are most likely responsible for the differences in these benthic communities, but further study is necessary to assess direct causation. It is likely that the hypoxiainduced prey limitation and subsequent trophic shifts are merely some of many changes to the structure and function of benthic communities that might be occurring in eutrophic estuaries.

\section{Benthic community response to eutrophication and hypoxia}

There were marked differences between the 2 estuaries at all levels of the benthic community as a result of complex interactions among nutrients, flora, and fauna. The increased occurrence of algal blooms increases the frequency and duration of hypoxia in eutrophic estuaries, and is likely the mechanism driving changes in benthic invertebrate community composition and the reduced abundance of invertebrates in CR (Tables 3 \& 4, Fig. 2) and other estuaries worldwide (Sogard \& Able 1991, Isaksson \& Pihl 1992, Geertz-Hansen et al. 1993, Norkko \& Bonsdorff 1996, Tagliapietra et al. 1998). In CR, there were approximately $90 \%$ fewer benthic consumers than in SLP (Table 4). A similar pattern was observed in surveys and experimental studies in the Baltic Sea, which showed that abundances of zoobenthos declined approximately $90 \%$ in areas with macroalgal mats and lower dissolved oxygen concentrations (Norkko \& Bonsdorff 1996). In contrast to these results, a 3-fold increase in macrofaunal abundance and higher numbers of grazers in macroalgal habitats relative to seagrasses were found in a survey of consumers in Venice Lagoon by Balducci et al. (2001). In the non-eutrophic estuary surveyed in the present study, the number and abundances of taxa tended to be higher than those reported in the literature for comparable temperate habitats (Sogard \& Able 1991, Norkko \& Bonsdorff 1996, Balducci et al. 2001, Wennhage \& Pihl 2007).

Smaller, less mobile crustaceans, such as amphipods and isopods, are more sensitive to eutrophication, and these crustacean taxa dominated the faunal assemblage in the non-eutrophic estuary but were rarer in the eutrophic estuary (Tables 3 \& 4), most likely because they were unable to tolerate the intermittent and persistent hypoxia associated with the macroalgal blooms (Harper et al. 1981, Geertz-Hansen et al. 1993, Wicklund \& Sundelin 2001). Gammarus mucronatus was the dominant amphipod species in the eutrophic estuary (Table 4). This may be in part because gammaridean amphipods have been shown to tolerate moderate hypoxia by migrating vertically out of hypoxic bottom waters; however, in doing so they significantly increase risk of predation (Kolar \& Rahel 1993). In contrast, Corophium spp. abundance has been shown to decrease in the presence of macroalgal mats (Kidwai \& Rafaelli 2000, Österling \& Pihl 2001), supporting our observation of the significant decrease in abundance of Corophium spp. in the eutrophic estuary relative to the non-eutrophic estuary (Table 4 ). The lethal and sub-lethal effects of hypoxia are likely to reduce the abundance of amphipods and isopods in eutrophic estuaries that experience persistent moderate hypoxia, like CR (Tables 2 \& 3, Fig. 2). Harper et al. (1981) found that hypoxia off the Texas coast led to a loss of amphipod diversity and abundances. In general, hypoxia of $<2 \mathrm{mg} \mathrm{l}^{-1}$ has been shown to affect consumer behavior and survival (Dauer et al. 1992, Rabalais et al. 2001), but moderate hypoxia $\left(<4 \mathrm{mg} \mathrm{l}^{-1}\right)$ may impair invertebrate reproduction (Coiro et al. 2000, Eriksson Wiklund \& Sundelin 2001), and cause slow growth in crustaceans (Coiro et al. 2000) and polychaetes (Forbes \& Lopez 1990).

A few taxa were common to both estuaries, including polychaetes, gastropods, and shrimp (Tables 3 \& 4). Of the common polychaetes and gastropods found in this study, Nereis succinea, Streblospio benedicti, Capitellidae, and Hydrobia spp. are opportunistic taxa associated with macroalgal mats, and may be tolerant of anthropogenic disturbances to estuarine and coastal waters (Norkko \& Bonsdorff 1996, Tagliapietra et al. 
1998, Ritter \& Montagna 1999, Österling \& Pihl 2001, Hyland et al. 2004). Cummins et al. (2004) experimentally added macroalgae to plots in an Australian estuary and found that, when compared to controls, algal addition led to an increase in gastropods, and a decrease in polychaetes (spionids, orbinids, and capitellids) and crustaceans (infaunal amphipods), supporting our findings of increasing gastropod and decreasing amphipod abundances. However, the polychaete responses may differ, since polychaetes of these 3 groups were common in CR (Table 4), but these results are difficult to compare since the Australian polychaetes were not identified to species level (Cummins et al. 2004).

Some benthic species are tolerant of low dissolved oxygen concentrations (Llanso 1991, Dauer et al. 1992, Ritter \& Montagna 1999, Sagasti et al. 2000), and larger, more mobile taxa may be able to avoid areas of hypoxia (Breitburg 1992, Rabalais et al. 2001). Shrimp of the genus Palaemonetes were common in both estuaries (Tables $3 \& 4$ ) and have been shown to tolerate hypoxia lasting multiple days. Although shrimp growth and larval survival can be affected by eutrophication and hypoxia (Coiro et al. 2000), Millman et al. (2002) found that fecundity was not affected by the level of eutrophication and that shrimp abundance increased with increasing nitrogen load, corroborating the slightly higher abundance of Palaemonetes spp. observed in CR relative to SLP (Table 4). In New Jersey estuaries, Sogard \& Able (1991) also found P. vulgaris and Crangon septemspinosa in high densities in both seagrass and macroalgal habitats. Certain taxa, such as Palaemonetes spp., thrive under eutrophic conditions by taking advantage of the increase in primary production and changes in prey behavior (Ritter \& Montagna 1999, Sagasti et al. 2000, Dauer et al. 1992); however, the species that persist may have to alter their feeding patterns to survive.

Some taxa change their feeding and foraging behavior in response to hypoxia (Llanso 1991, Breitburg 1992, Rabalais et al. 2001), while others alter their energy allocation (Cheung et al. 2008). The gastropod Ilyanassa sp. alters energy allocation under hypoxic conditions to enhance survival (Cheung et al. 2008), and this strategy might also be employed by $I$. obsoleta, which was the only taxon that was significantly more abundant in the eutrophic estuary than in the non-eutrophic estuary (Table 4). The Ulva detritus, which is ubiquitous in $\mathrm{CR}$, might be supporting the high numbers of I. obsoleta observed in this estuary, since this gastropod is attracted to areas with high levels of Ulva detritus (Kelaher et al. 2003). The $\delta^{15} \mathrm{~N}$ values of these gastropods in $\mathrm{CR}$, however, suggest that a larger proportion of their diet is likely coming from living macroalgal tissues than from detritus.
These gastropods are known to consume large amounts of Ulva and are capable of controlling macroalgal growth under low, but not under high, nutrient conditions (Giannotti \& McGlathery 2001). In Waquoit Bay, the grazer community was also unable to control macroalgal growth in the higher nitrogen loaded estuaries (S. Fox et al. unpubl. data).

\section{Top-down control of benthic invertebrates}

An alternative to eutrophication and hypoxia as the explanation for the reduced abundance of invertebrates in CR might be top-down control by predators. Although fish were not sampled in the abundance study, predatory fish are present in these estuaries, with significantly more of the benthos-feeding Fundulus heteroclitus in CR than in SLP (Tober et al. 2000). Another predatory fish, Menidia menidia, was equally abundant in both estuaries and 3 to $9 \times$ more abundant than F. heteroclitus. The higher abundances of F. heteroclitus in $\mathrm{CR}$ may be exerting top-down control on the grazers in this estuary by consuming smaller invertebrates. A cage experiment examining top-down control by fish in the estuaries of Waquoit Bay, however, showed that fish controlled amphipod abundances in SLP while having no effect in CR. In contrast, polychaete abundance might be controlled by fish in CR and not in SLP (Behr 1997). Fish might, however, be able to nearly decimate the grazer community that has already been severely impacted by hypoxia, so that some synergistic interaction may occur between abiotic factors (i.e. nutrients and hypoxia) and biotic factors (i.e. diet switching and predation).

\section{Benthic food web changes}

In Waquoit Bay, there were few crustacean prey in the eutrophic estuary and, in the absence of prey, omnivores in the eutrophic estuary facultatively shifted to feeding on macroalgae, which was an abundant resource. In other systems, crustaceans have been forced by prey limitation to shift from preferred prey species to other available prey (Kidwai \& Rafaelli 2000), or to shift from invertebrate prey to algae or detritus (Edgar 1990, Parkyn et al. 2001, Jephson et al. 2008, Persson et al. 2008). Jephson et al. (2008) and Persson et al. (2008) showed that Palaemon spp. switch to feeding on macroalgae in the absence of their preferred small amphipod and isopod prey, supporting the finding that Palaemonetes spp. and other omnivores switch from omnivory to consuming more macroalgae in the eutrophic estuary owing to prey limitation. 

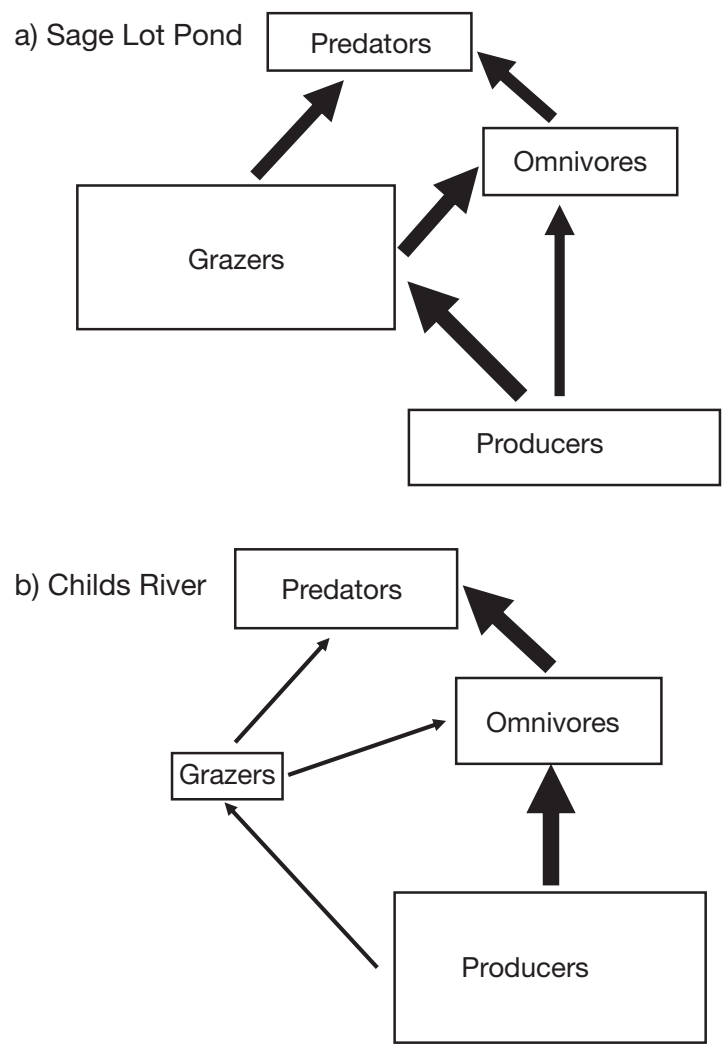

Fig. 4. Schematic of food webs inferred from survey and stable isotopic data for (a) Sage Lot Pond and (b) Childs River. Size of boxes indicates relative abundance of trophic levels and width of arrows represents strength of the energy transfer

In the present study, stable isotope ratios differentiated between functional and trophic roles of omnivores. $\delta^{15} \mathrm{~N}$ values of CR omnivores revealed incorporation of the macroalgal food source into body tissues, since the $\delta^{15} \mathrm{~N}$ values of omnivores were not significantly different from $\delta^{15} \mathrm{~N}$ values of grazers, solidifying their role as both functional and trophic herbivores. In contrast, other crustaceans have been shown to be functional omnivores by gut content analysis, feeding on invertebrates and detritus, but stable isotopic analysis defined these crustaceans as trophic predators, indicating that the detritus in their guts was not incorporated into body mass (Parkyn et al. 2001). In the eutrophic estuary in Waquoit Bay, where herbivores were rare, some omnivores may have been forced to feed as herbivores because of limited prey.

The large decrease in the number of grazers in the eutrophic estuary must have consequences for higher trophic levels, since small crustacean grazers are a major food source for omnivores and predators (Nelson 1979, MacNeil et al. 1999, McCurdy et al. 2005). Using the food webs of Waquoit Bay as examples, we provide a conceptual model of how eutrophication may force changes in food webs (Fig. 4). In SLP, under noneutrophic conditions, energy from primary production was converted by the abundant grazers to nutritional energy available to higher trophic levels (Fig. 4a). Omnivores and predators took advantage of the higher energy transfer per unit of biomass of their highly nutritional prey. Eutrophication, by indirectly reducing the abundance of invertebrate grazers, altered the energy flow through the trophic web by transferring energy from primary production directly to omnivores, which took on the functional and trophic roles of herbivores (Fig. 4b). The proportion of energy transferred up the food web to predators through omnivores was higher in the eutrophic estuary than in the noneutrophic estuary.

As trophic herbivores, CR omnivores may feed with reduced efficiency. Growth rates of omnivorous invertebrates may be higher when they consume invertebrate prey than when they eat algae (Edgar 1990), since algae are of low nutritional quality and must be consumed in larger amounts (Parkyn et al. 2001, Fagan \& Denno 2004). Omnivores in CR, however, might not be at an energetic disadvantage, because of the higher nutritional quality of nitrogen-enriched macroalgae in eutrophic estuaries (Galan Jimenez et al. 1996), especially since consumers in coastal food webs are often nitrogen limited (Fagan \& Denno 2004). Omnivores should receive energetic benefits from consuming macroalgae from eutrophic estuaries since, in food choice experiments, grazers always preferred nitrogen-enriched macroalgae (Martinez et al. 1995, Hemmi \& Jormalainen 2002). The lack of energetic consequences for omnivores switching to herbivory in the eutrophic estuary was corroborated by the higher abundances of shrimp, the dominant omnivore, in CR than in SLP (our Table 4; Millman et al. 2002). In addition, the altered trophic energy flow in the CR food web (Fig. 4) did not appear to create energetic consequences for predators, since the abundance and growth rates of fish were higher in CR than in SLP (Tober et al. 2000). Although eutrophication and hypoxia in CR likely altered energy flow through the benthic food web, energy transfer to higher trophic levels appeared to be efficient with no detectable consequences for the abundance of shrimp and fish in these estuaries.

Future studies involving trophic interactions should be careful when assigning species to trophic levels because consumers may shift food choices depending on their mobility, prey availability, prey size and predation pressure, and they may 'cross' trophic classifications (Nelson 1979, Nicotri 1980, Edgar 1990, Parkyn et al. 2001, Trussell et al. 2006). Trophic roles of producers and herbivores are clear in most food webs, but 
for non-herbivore consumers trophic levels are an abstraction and can be described more correctly as a 'trophic tangle' (Thompson et al. 2007).

\section{CONCLUSIONS}

Eutrophication of coastal waters has led to macroalgae-dominated estuaries with moderate intermittent hypoxia, causing significant changes to benthic community structure and food web relationships. Many benthic consumers are unable to survive the degradation of water quality associated with high nutrient loading. Those that are the most tolerant, like Palaemonetes spp., are omnivores with flexible generalist diets that are able to take advantage of eutrophic conditions and new resources and, in doing so, change their function in the benthic food web. By filling the trophic vacancy, these omnivores may be able to maintain the stability of anthropogenically impacted coastal communities and their food webs.

Acknowledgements. We thank L. Fox for assistance in the field and the laboratory. This research was supported by the following funding sources: NOAA National Estuarine Research Reserve and EPA STAR Graduate Research Fellowships to S.E.F., Palmer McCleod Fellowship awarded to M.T., Woods Hole Marine Science Consortium undergraduate internship awarded to L.H., and NOS/ECOHAB grant \#NA16OP2728.

\section{LITERATURE CITED}

Baden SP, Loo LO, Pihl L, Rosenberg R (1990) Effects of eutrophication on benthic communities including fish: Swedish west coast. Ambio 19:113-122

Balducci C, Sfriso A, Pavoni B (2001) Macrofauna impact on Ulva rigida C. Ag. production and relationship with environmental variables in the lagoon of Venice. Mar Environ Res 52:27-49

Behr PJ (1997) The effects of nitrogen loads on fish and the effects of fish on macrobenthos in Waquoit Bay. MA thesis, Boston University, Boston, MA

Bowen JL, Valiela I (2001) The ecological effects of urbanization of coastal watersheds: historical increases in nitrogen loads and eutrophication of Waquoit Bay. Can J Fish Aquat Sci 58:1489-1500

Breitburg DL (1992) Episodic hypoxia in Chesapeake Bay: interacting effects of recruitment, behavior, and physical disturbance. Ecol Monogr 62:525-546

Bricker S, Longstaff B, Dennison W, Jones A, Boicourt K, Wicks C, Woerner J (2007) Effects of nutrient enrichment in the nation's estuaries: a decade of change. NOAA coastal ocean program decision analysis series no. 26. National Centers for Coastal Ocean Science, Silver Spring, MD

Brownlee KA (1965) Statistical theory and methodology in science and engineering, 2nd edn. John Wiley \& Sons, New York

Carmichael RH, Valiela I (2005) Coupling of near-bottom seston and surface sediment composition: changes with nutri- ent enrichment and implications for estuarine food supply and biogeochemical processing. Limnol Oceanogr 50: 97-105

> Cheung SG, Chan HY, Liu CC, Shin PKS (2008) Effect of prolonged hypoxia on food consumption, respiration, growth and reproduction in marine scavenging gastropod Nassarius festivus. Mar Pollut Bull 57:280-286

Cloern JE (2001) Our evolving conceptual model of the coastal eutrophication problem. Mar Ecol Prog Ser 210: 223-253

Coiro LL, Poucher SL, Miller DC (2000) Hypoxic effects on growth of Palaemonetes vulgaris larvae and other species: using constant exposure to estimate cyclic exposure response. J Exp Mar Biol Ecol 247:243-255

Cole ML, Valiela I, Kroeger KD, Tomasky GL and others (2004) Assessment of a $\delta^{15} \mathrm{~N}$ isotopic method to indicate anthropogenic eutrophication in aquatic ecosystems. J Environ Qual 33:124-132

Costanzo SD, O'Donohue MJ, Dennison WC, Loneragan NR, Thomas M (2001) A new approach for detecting and mapping sewage impacts. Mar Pollut Bull 42:149-156

Crawley KR, Hyndes GA, Vanderklift MA (2007) Variation among diets in discrimination of $\delta^{13} \mathrm{C}$ and $\delta^{15} \mathrm{~N}$ in the amphipod Allorchestes compressa. J Exp Mar Biol Ecol 349:370-377

Cummins SP, Roberts DE, Zimmerman KD (2004) Effects of the green macroalga Enteromorpha intestinalis on macrobenthic and seagrass assemblages in a shallow coastal estuary. Mar Ecol Prog Ser 266:77-87

> D'Avanzo C, Kremer JN (1994) Diel oxygen dynamics and anoxic events in an eutrophic estuary of Waquoit Bay, Massachusetts. Estuaries 17:131-139

Dauer DM, Rodi AJ, Ranasinghe JA (1992) Effects of low dissolved oxygen events on the macrobenthos of the lower Chesapeake Bay. Estuaries 15:384-391

$>$ Diaz RJ (2001) Overview of hypoxia around the world. J Environ Qual 30:275-281

Diaz RJ, Rosenberg R (2001) Overview of anthropogenicallyinduced hypoxic effects on marine benthic fauna. In: Rabalais NN, Turner RE (eds) Coastal hypoxia: consequences for living resources and ecosystems. American Geophysical Union, Washington, DC, p 129-145

Diaz RJ, Rosenberg R (2008) Spreading dead zones and consequences for marine ecosystems. Science 321:926-929

Duarte C (1995) Submerged aquatic vegetation in relation to different nutrient regimes. Ophelia 41:87-112

Edgar GJ (1990) Predator-prey interactions in seagrass beds. I. The influence of macrofaunal abundance and size-structure on the diet and growth of the western rock lobster Panulirus Cygnus George. J Exp Mar Biol Ecol 139:1-22

Eriksson Wicklund AK, Sundelin B (2001) Impaired reproduction in the amphipods Monoporeia affinis and Pontoporeia femorata as a result of moderate hypoxia and increased temperature. Mar Ecol Prog Ser 222:131-141

Fagan WF, Denno RF (2004) Stoichiometry of actual vs. potential predator-prey interactions: insights into nitrogen limitation for arthropod predators. Ecol Lett 7:876-883

Forbes TL, Lopez GR (1990) The effect of food concentration, body size, and environmental oxygen tension on the growth of the deposit-feeding polychaete, Capitella species 1. Limnol Oceanogr 35:1535-1544

Fox SE (2008) Ecological effects of nitrogen loading to temperate estuaries: macrophyte and consumer community structure and food web relationships. PhD dissertation, Boston University, Boston, MA

Fox SE, Stieve E, Valiela I, Hauxwell J, McClelland J (2008) Macrophyte abundance in Waquoit Bay: effects of land- 
derived nitrogen loads on seasonal and multi-year biomass patterns. Estuaries Coasts 31:532-541

Galan Jimenez EG, Hauxwell J, Heckscher E, Rietsma C, Valiela I (1996) Selection of nitrogen-enriched macroalgae (Cladophora vagabunda and Gracilaria tikvahiae) by the herbivorous amphipod Microdeutopus gryllotalpa. Biol Bull 191:323-324

Geertz-Hansen O, Sand-Jensen K, Hansen DF, Christiansen A (1993) Growth and grazing control of abundance of the marine macroalga, Ulva lactuca L. in a eutrophic Danish estuary. Aquat Bot 46:101-109

- Giannotti AL, McGlathery KJ (2001) Consumption of Ulva lactuca (Chlorophyta) by the omnivorous mud snail Ilyanassa obsoleta (Say). J Phycol 37:209-215

Griffin MPA, Valiela I (2001) $\delta^{15} \mathrm{~N}$ isotope studies of life history and trophic position of Fundulus heteroclitus and Menidia menidia. Mar Ecol Prog Ser 214:299-305

Harper DE, McKinney LD, Salzer RR, Case RJ (1981) The occurrence of hypoxic bottom water off the upper Texas coast and its effect on the benthic biota. Contrib Mar Sci 24:53-79

Hauxwell J, Cebrian J, Furlong C, Valiela I (2001) Macroalgal canopies contribute to eelgrass (Zostera marina) decline in temperate estuarine ecosystems. Ecology 82:1007-1022

> Heck KL Jr, Thoman TA (1981) Experiments on predatorprey interactions in vegetated aquatic habitats. J Exp Mar Biol Ecol 53:125-134

Hemmi A, Jormalainen V (2002) Nutrient enhancement increases performance of a marine herbivore via quality of its food alga. Ecology 83:1052-1064

Holmes GT (2008) Nutrient supply, water residence time, temperature, and grazing as controls of size-fractionated phytoplankton biomass in shallow temperate estuarine ecosystems. PhD thesis, Boston University, Boston, MA

- Hyland JL, Balthis WL, Posey M, Hackney CT, Alphin T (2004) The soft-bottom macrobenthos of North Carolina estuaries. Estuaries 27:501-514

Isaksson I, Pihl L (1992) Structural changes in benthic macrovegetation and associated epifaunal benthic communities. Neth J Sea Res 30:131-140

> Jephson T, Nyström P, Moksnes PO, Baden SP (2008) Trophic interactions in Zostera marina beds along the Swedish coast. Mar Ecol Prog Ser 369:63-76

Kelaher BP, Levinton JS, Hoch JM (2003) Foraging by the mud snail, Ilyanassa obsoleta (Say), modulates spatial variation in benthic community structure. J Exp Mar Biol Ecol 292:139-157

Kidwai S, Raffaelli D (2000) Food selection and growth patterns of Crangon crangon L. in the presence of macroalgal mats: field experiment on the Ythan estuary (Aberdeenshire, Scotland). Pak J Zool 32:201-206

Kneib RT (1985) Predation and disturbance by grass shrimp, Palaemonetes pugio Holthius, in soft-substratum benthic invertebrate assemblages. J Exp Mar Biol Ecol 93:91-102

Kolar CS, Rahel FJ (1993) Interaction of a biotic factor (predator presence) and an abiotic factor (low oxygen) as an influence on benthic invertebrate communities. Oecologia 95:210-219

Lever MA, Valiela I (2005) Response of microphytobenthic biomass to experimental nutrient enrichment and grazer exclusion at different land-derived nitrogen loads. Mar Ecol Prog Ser 294:117-129

> Llanso RJ (1991) Tolerance of low dissolved oxygen and hydrogen sulfide by the polychaete Streblospio benedicti (Webster). J Exp Mar Biol Ecol 153:165-178

Macko SA, Lee WY, Parker PL (1982) Nitrogen and carbon isotope fraction by two species of marine amphipods: laboratory and field studies. J Exp Mar Biol Ecol 63:145-149
MacNeil C, Dick JTA, Elwood RW (1999) The dynamics of predation on Gammarus spp. (Crustacea: Amphipoda). Biol Rev Camb Philos Soc 74:375-395

> Martinetto P, Teichberg M, Valiela I (2006) Coupling of estuarine benthic and pelagic food webs to land-derived nitrogen sources in Waquoit Bay, Massachusetts, USA. Mar Ecol Prog Ser 307:37-48

Martinez N, Hauxwell J, Valiela I (1995) Effect of macroalgal species and nitrogen loading rates in colonization of macroalgae by herbivorous amphipods. Biol Bull 189: 244-245

McClelland JW, Valiela I (1998a) Linking nitrogen in estuarine producers to land-derived sources. Limnol Oceanogr 43:577-585

McClelland JW, Valiela I (1998b) Changes in food web structure under the influence of increased anthropogenic nitrogen inputs to estuaries. Mar Ecol Prog Ser 168:259-271

McClelland JW, Valiela I, Michener RH (1997) Nitrogenstable isotope signatures in estuarine food webs: a record of increasing urbanization in coastal watersheds. Limnol Oceanogr 42:930-937

McCurdy DG, Forbes MR, Logan SP, Lancaster D, Mautner SI (2005) Foraging and impacts by benthic fish on the intertidal amphipod Corophium volutator. J Crustac Biol 25: 558-564

> McGlathery KJ (2001) Macroalgal blooms contribute to decline of seagrass in nutrient-enriched coastal waters. J Phycol 37:453-456

- Millman M, Teichberg M, Martinetto P, Valiela I (2002) Response of shrimp populations to land-derived nitrogen in Waquoit Bay, Massachusetts. Biol Bull 203:263-264

Minagawa M, Wada E (1984) Stepwise enrichment of ${ }^{15} \mathrm{~N}$ along food chains: further evidence and the relation between $\delta^{15} \mathrm{~N}$ and animal age. Geochim Cosmochim Acta 48:1135-1140

Morgan MD (1980) Grazing and predation of the grass shrimp Palaemonetes pugio. Limnol Oceanogr 25:896-902

- Nelson WG (1979) Experimental studies of selective predation on amphipods: consequences for amphipod distribution and abundance. J Exp Mar Biol Ecol 38:225-245

Nicotri ME (1980) Factors involved in herbivore food preference. J Exp Mar Biol Ecol 42:13-26

Nixon SW (1992) Quantifying the relationship between nitrogen input and the productivity of marine ecosystems. Proc Advancements Mar Technol Conf, Tokyo 5:57-83

> Norkko A, Bonsdorff E (1996) Population responses of coastal zoobenthos to stress induced by drifting algal mats. Mar Ecol Prog Ser 140:141-151

Österling M, Pihl L (2001) Effects of filamentous green algal mats on benthic macrofaunal functional feeding groups. J Exp Mar Biol Ecol 263:159-183

Parkyn SM, Collier KJ, Hicks BJ (2001) New Zealand stream crayfish: functional omnivores but trophic predators? Freshw Biol 46:641-652

Persson M, Andersson S, Baden S, Moksnes PO (2008) Trophic role of the omnivorous grass shrimp Palaemon elegans in a Swedish eelgrass system. Mar Ecol Prog Ser 371:203-212

Peterson BJ, Fry B (1987) Stable isotopes in ecosystem studies. Annu Rev Ecol Syst 18:293-320

Pihl L (1994) Changes in the diet of demersal fish due to eutrophication-induced hypoxia in the Kattegat, Sweden. Can J Fish Aquat Sci 51:321-336

Rabalais NN, Harper DE Jr, Turner RE (2001) Responses of nekton and demersal and benthic fauna to decreasing oxygen concentrations. In: Rabalais NN, Turner RE (eds) 
Coastal hypoxia: consequences for living resources and ecosystems. American Geophysical Union, Washington, DC, p. 115-128

Ritter C, Montagna PA (1999) Seasonal hypoxia and models of benthic response in a Texas bay. Estuaries 22:7-20

Safran RE, Legra JC, Valiela I (1998) Effects of nitrogen loading on eelgrass seed coat abundance, $\mathrm{C}$ to $\mathrm{N}$ ratios, and $\delta^{15} \mathrm{~N}$ in sediments of Waquoit Bay. Biol Bull 195:245-246

Sagasti A, Schaffner LC, Duffy JE (2000) Epifaunal communities thrive in an estuary with hypoxic episodes. Estuaries 23:474-487

Sogard SM, Able KW (1991) A comparison of eelgrass, sea lettuce macroalgae, and marsh creeks as habitats for epibenthic fishes and decapods. Estuar Coast Shelf Sci 33: 501-519

Tagliapietra D, Pavan M, Wagner C (1998) Macrobenthic community changes related to eutrophication in Palude della Rosa (Venetian Lagoon, Italy). Estuar Coast Shelf Sci 47:217-226

Teichberg M, Heffner LR, Fox S, Valiela I (2007) Nitrate reductase and glutamine synthetase activity, internal $\mathrm{N}$ pools, and growth of Ulva lactuca: responses to long and short-term N supply. Mar Biol 151:1249-1259

Thompson RM, Hemberg M, Starzomski BM, Shurin JB (2007) Trophic levels and trophic tangles: the prevalence of omnivory in real food webs. Ecology 88:612-617

Editorial responsibility: Kenneth Heck, Dauphin Island, Alabama, USA
Tober JD, Griffin MPA, Valiela I (2000) Growth and abundance of Fundulus heteroclitus and Menidia menidia in estuaries of Waquoit Bay, Massachusetts exposed to different rates of nitrogen loading. Aquat Ecol 34:299-306

Trussell GC, Ewanchuk PJ, Matassa CM (2006) The fear of being eaten reduces energy transfer in a simple food chain. Ecology 87:2979-2984

Valiela I, Foreman K, LaMontagne M, Hersh D and others (1992) Couplings of watersheds and coastal waters: sources and consequences of nutrient enrichment in Waquoit Bay, Massachusetts. Estuaries 15:443-457

Vander Zanden MJ, Rasmussen JB (2001) Variation in $\delta^{15} \mathrm{~N}$ and $\delta^{13} \mathrm{C}$ trophic fractionation: implications for aquatic food web studies. Limnol Oceanogr 46:2061-2066

Vanderklift MA, Ponsard S (2003) Sources of variation in consumer-diet $\delta^{15} \mathrm{~N}$ enrichment: a meta-analysis. Oecologia 136:169-182

Ware DM, Thompson RE (2005) Bottom-up ecosystem trophic dynamics determine fish production in northeast Pacific. Science 308:1280-1284

Wennhage H, Pihl L (2007) From flatfish to sticklebacks: assemblage structure of epibenthic fauna in relation to macroalgal blooms. Mar Ecol Prog Ser 335:187-198

Zimmerman R, Gibson R, Harrington J (1979) Herbivory and detritivory among gammaridean amphipods from a Florida seagrass community. Mar Biol 54:41-47

Submitted: June 6, 2008; Accepted: January 6, 2009 Proofs received from author(s): March 30, 2009 